\title{
DESIGNING EXPLANATIONS IN THE RECOMMENDER SYSTEMS BASED ON THE PRINCIPLE OF A BLACK BOX
}

\begin{abstract}
The subject matter of the article is the process of designing of explanations in the recommender system. The goal is to develop a conceptual model for designing explanations in recommender systems based on the black box principle. Such a model binds the conditions, the result and the constraints on the choice of objects from the user's position. The user should receive justification of the recommendations taking into account context-oriented possibilities of using the proposed objects. Tasks: to adapt the principle of a black box to the task of constructing explanations in the recommender system; to develop a conceptual scheme for constructing explanations according to the functional principle; to develop a conceptual model for the designing of explanations based on the principle of a black box. The principle used is: functional, or the principle of a black box. The following results are obtained. The principle of the black box to the problem of constructing explanations in the recommender system was adapted. The conceptual scheme of constructing explanations on the basis of a functional principle is developed, taking into account both the properties of objects and the sequences of their use. The conceptual model of the explanation based on the black box principle is developed. Conclusions. Scientific novelty of the results is as follows. The conceptual model for constructing explanations with recommendations on the functional principle or the principle of a black box is proposed. The model takes into account the characteristics of subjects and consumers, information on the use of objects in the subject area, as well as recommendations in the form of a list of objects. The advantage of using the proposed model lies in the fact that it takes into account the methods of applying the recommended objects for constructing explanations. This creates conditions for personalizing recommendations in cases of a cold start of the recommender system, as well as artificial increase in the ratings of individual items.
\end{abstract}

Keywords : recommender systems; e-commerce systems; explanation; the context of decision-making; the formation of recommendations; the formation of explanations.

\section{Introduction}

Recommendation systems are intended for the designing of a rating list with offers of goods and services for the consumer. Such systems form personalized offers for the user. The task of recommender system is to form an interesting list of objects for the consumer and encourage him to buy goods from this list [1].

These systems are typically part of e-commerce systems and use their database to formulate recommendations. The personalized list of objects simplifies the search and selection of goods for the user. This enables a group of loyal consumers to grow and increase sales in the e-commerce system. Therefore, such systems have become widespread $[2,3]$.

When constructing recommendations, account is taken of both the characteristics of objects and the characteristics of already known users of the recommendation system. In the first case, products that have similar parameters with the products selected by the current user are recommended. In the second case, it is recommended that objects previously chosen by consumers, similar to the current user of the recommendation system. Accordingly, inputs are used as product characteristics and their consumer-generated ratings [1].

However, practical requirements for improving the accuracy of the recommendations led to the problem of building an inaccurate list of objects for cold start cases and artificial distortion of the rating of objects.

The cold start situation occurs when building recommendations for new users. Usually information about the choice of such users is not available in the recommender system or e-commerce system. This does make it difficult to compare the new user with existing ones and to find similar characteristics in them [5].

The situation of artificial distortion of rating of objects is used for the promotion of individual goods [6]. The purpose of such actions is to sell objects with false ratings.

An explanation is used to solve the problem of building an inaccurate list of recommended objects. The latter describe the sequence of obtaining and the possibility of using the proposed recommendations. Explanations allow the user to better understand the reasons for the recommendations and the context and the way to use the recommended objects [7]. Designing of explanations is aimed at increasing consumer confidence in the e-commerce system [8].

Modern approaches to constructing explanations in recommender systems are the further development of methods for constructing explanations in expert systems [9]. When constructing explanations, the criteria for evaluating explanations are used, as well as the precedents for using explanations and restrictions of the subject area that influence the explanation [10]. However, the context-based concept of explanation based on the introduction of a reference system in the form of a black box requires further research. The above determines the relevance of this work.

The purpose of the article is to develop a conceptual model for the formation of explanations in recommender systems based on the principle of a black box. This model uses the conditions, the result and the restrictions on the choice of objects from the user's position. The user should receive the justification of the recommendations taking into account the contextoriented possibilities of using the proposed objects. 
To achieve this goal, the following tasks need to be addressed: to adapt the principle of a black box to the task of constructing explanations in the recommender system; to develop the conceptual scheme of construction of explanations according to the functional principle; to develop a conceptual model of explanation based on the principle of a black box.

\section{Conceptual model of explanation based on the principle of a black box}

The proposed conceptual model is based on the use of the principle of a black box, or a functional principle. The latter is widely used in software testing.

According to this principle, the system is considered at the level of "input-output". The internal structure of the system and the sequence of the interaction of its elements are not taken into account or are unknown.

The conceptual scheme of constructing explanations in the recommender systems according to the functional principle is presented in Fig. 1.

We substantiate the use of the black box principle to formulate explanations in the reference systems according to the presented conceptual scheme.

Firstly, the explanation is intended to interpret the recommended list of objects in the context of the subject area. Such an interpretation makes it possible to clarify the way of using the proposed objects. That is, an explanation describes the links of the recommended objects with other objects of the subject area. Such connections are not static. They change over time, depending, for example, on the season, new scientific achievements, fashion, etc.

Therefore, the explanation in this case is contextoriented and shows the possibility of using objects in a defined context [11].

Secondly, the context of the explanation is determined not only by the approaches to the use of objects with similar characteristics, but also by models of the subject area. For example, in the context of buying a computer, a flash drive, a bag for that computer, and the like can be offered.

When forming such a recommendation, it usually takes into account the purchase of people with similar interests who buy a computer and a flash drive or a bag. However, this static information is not enough to explain the recommendation.

You should also consider the sequence of user choices in time. Buying a computer and a flash drive defines a temporal rule that binds these two objects in time. The set of such temporal rules forms a contextoriented domain model. The domain model may also be a priori known, formal or case-law. For example, a formal model can set limits on the power of recommended products.

The precedent model sets out the known methods of their use in the form of a sequence of appropriate actions.

The following example shows that additional knowledge of the subject area can be obtained not only a priori, but also as a result of the intellectual analysis of existing data about objects, users, and their choice.

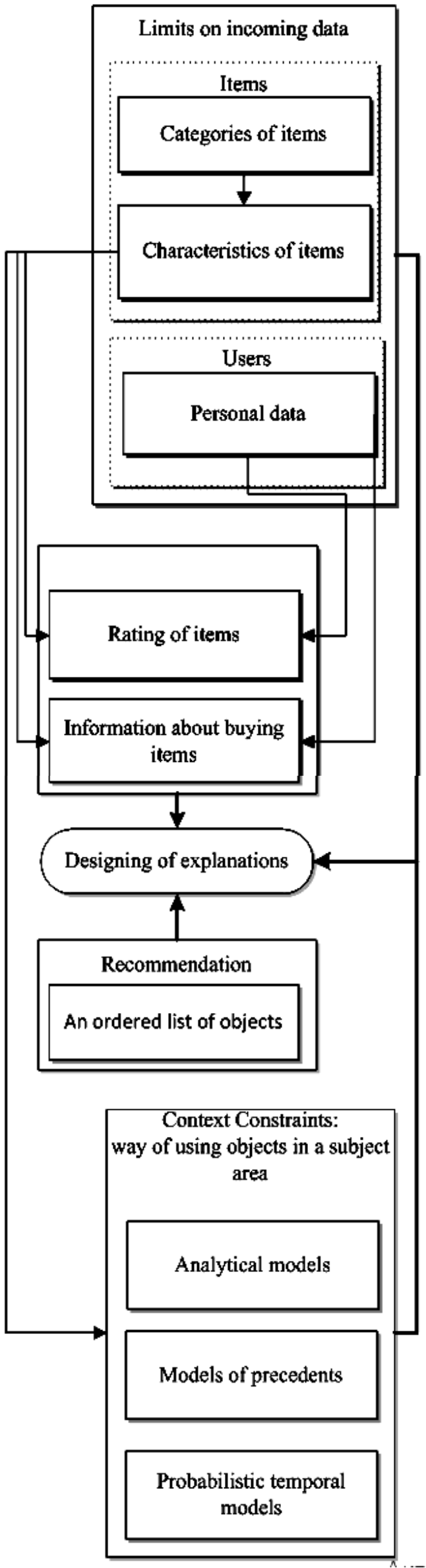

Fig. 1. Conceptual scheme of designing an explanation based on the black box principle 
A key feature of such an analysis is that it is necessary to take into account the orderliness of the events of the choice of objects in time. This makes it possible to obtain heuristic dependencies characterizing the context-oriented use of the recommended objects.

Thus, the key differences in the concept of constructing explanations based on the principle of a black box are as follows.

1) A combination of restrictions on incoming data and restrictions on the use of recommended facilities. The first restriction makes it possible to justify the selection of a subset of the recommended objects. The purpose of the second limitation is to identify the context differences between the recommended objects.

2) The use of temporal ordering of the choice or application of objects. Such orderliness is typical for analytical, case-law and probabilistic models. In fact, the use of temporal order adds another dimension to the traditional static characteristics of objects. This makes it possible to take into account the temporal changes of such properties.

For example, when choosing a computer it is necessary to take into account not only its current properties (processor speed, memory size), but also quantitative possibilities of its modernization. In particular, the maximum possible amount of memory, hard disk, characteristics of additional connectors, etc. It is also advisable to take into account the cost and design features of these elements, such as their interfaces, performance. Additionally, it is also advisable to take into account the sequence of upgrades. For example, the amount of RAM can be increased in several stages, depending on the cost of the components.

An example of the use of restrictions on incoming data and temporal ordering in accordance with the concept of constructing explanations based on the black box is presented in Fig. 2

Initially, from the input subset of objects in the process of forming recommendations, elements are selected that satisfy the requirements for classes and properties of objects:

$$
\begin{aligned}
& \text { Item }^{*}=\left\{\text { Item }_{3}, \text { Item }_{4}: C=\text { true }\right\}, \\
& \text { Item }^{*} \subset \text { Item }
\end{aligned}
$$

where $C$ - the limit of the choice of the user; Item input set of items that is available for user selection; Item $^{*}$ - a subset of recommended items.

Subsequently, the elements of the subset Item $^{*}$ are compared by the methods that are usually used, in particular on the basis of temporal ordering of their application or modernization. Such orderliness can be represented in the form of temporal rules [12, 13]. In the future, these rules can be used to formulate explanations based on the probabilistic output [14]. Also, a multilayered graph [15] approach can be used to present constraints by way of use.

In Fig. 2 shows the sequence of use / product upgrade stages, for example, for a computer: incremental memory (step 1); replacement of hard disk (step 2); the next increase in RAM (Stage 3); complementing the computer to the WWAN module (step 4).

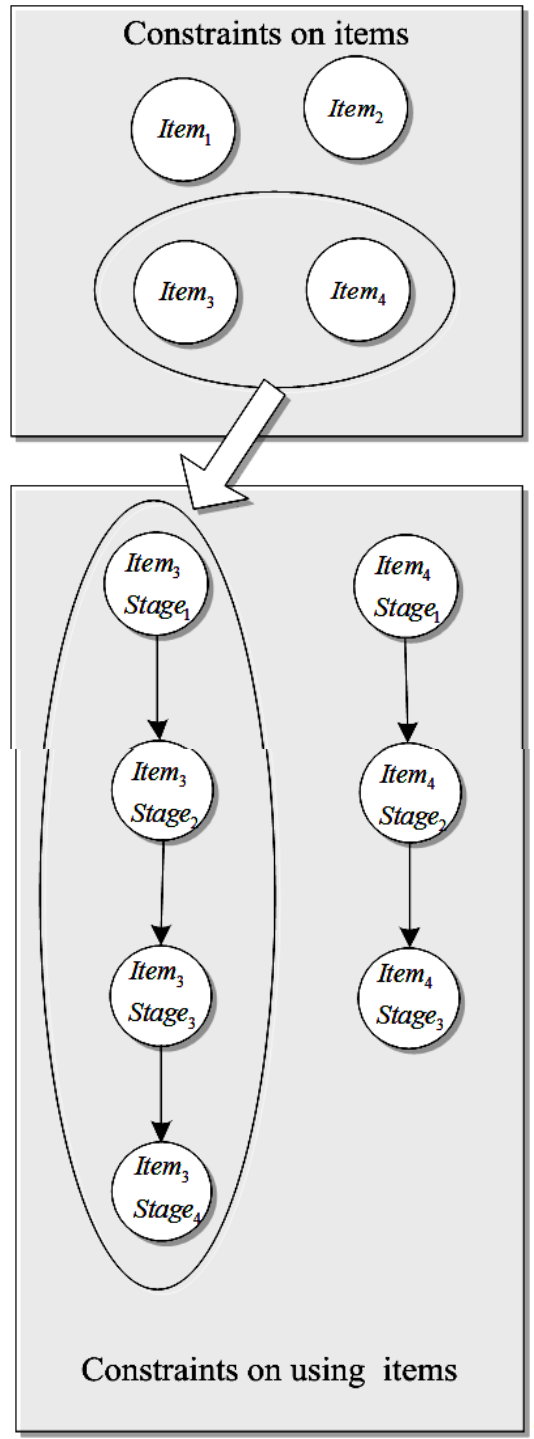

Fig. 2. An example of using restrictions in the concept of constructing explanations on the principle of a black box

The sequence has an additional possibility of upgrading - the connection of the WWAN module. But this feature is not necessary for all users.

Therefore, it is advisable to use this distinction when formulating explanations, thereby personalizing recommendations.

The conceptual model $B$ of explanation formation in the recommendation system based on the black box defines the display of the conditions $S$ of the choice of the user for the recommendation $R$, taking into account the general constraints. The latter are presented by restrictions $C$ on user selection $C$ and contextual restrictions $M$ on the use of objects from the recommended list.

This model has the following form:

$$
B: S \rightarrow R \mid C \wedge M .
$$

User-selectable rules for the BlackBerry model take into account only the results of choosing other consumers and do not take into account the interaction of the current user with the recommendation system. 
Therefore, such conditions are presented in the form of a set of object ratings for an explicit feedback situation (3) or the number of purchases of a product for an implicit feedback situation (4).

$$
S=\left\{\left(g_{i}, \rho_{j}\right): g_{i} \in G, 0 \leq \rho_{j}<\rho_{j}^{\max }\right\},
$$

where $g_{i}$ - the object (product, service), which has been chosen by the consumer; $\rho_{j}$ - ranking of the object; $G$ - a set of objects in the recommendation system.

$$
S=\left\{\left(g_{i}, \partial_{j}\right): g_{i} \in G, 0 \leq \partial_{j}\right\},
$$

where $\partial_{j}-$ the number of units of the object that has been purchased by the $j-$ the consumer.

The received recommendation $R$ contains an ordered list of objects $g_{i}$ according to the rating $r_{i}$, that is, it consists of a set of pairs $\left(g_{1}, r_{1}\right)$.

The restriction on the user's choice is a combination of restrictions on the characteristics of goods and user data. The restriction $C$ on the user's choice is a conjunction of restrictions on the characteristics of goods and user data.

Characteristics of goods are set both through the permissible values of all their properties, and through the generalized values of individual properties, that is, the affiliation of goods to a particular category.

Restrictions on users are asked in the same way, based on similar values of the characteristics of these users:

Restrictions on the use of objects are given on the basis of temporal rules [13], which relate the separate stages of the use or improvement of these objects, as shown in the example in Fig. 2.

\section{Conclusions}

The conceptual model of construction of explanations to recommendations on the principle of a black box is proposed. The model takes into account the characteristics of objects and users, information on the use of these objects in the subject area, as well as a list of objects recommended to the consumer. Characteristics of objects and users are used in the model as constraints. Information on the use of objects specifies the conditions for constructing explanations to the recommendations.

The advantages of the proposed model are that it allows for additional contextual information on how to apply the recommended goods or services.

Unlike the model based on the white box, this model should be considered as an explanatory model interpreting the recommendation, rather than the process of its designing in the recommender system.

\section{REFERENCES}

1. Aggarwal, C.C. (2017), Recommender Systems: The Textbook, Springer, New York, 498 p.

2. Bennet, J. and Lanning, S. (2019), The Netflix Prize [Proceedings of KDD cup and workshop], available at: http://www.netflixprize.com

3. Linden, G., Smith, B. and York J. (2003), "Amazon.com recommendations: Item-to-item collaborative filtering", Internet Computing, IEEE, vol. 7, no. 1, pp. 76-80.

4. Ricci, F., Rokach, L., Shapira, B. and Kantor, P. (2011), Recommender systems handbook, Springer, New York, 842 p.

5. Shilling, I. (2018), Attack detection for recommender systems based on credibility of group users and rating time series, DOI: https://doi.org/10.1371/journal.pone.0196533

6. Schein, A.I., Popescul, A., Ungar, L.H. and Pennock, D.M. (2002), "Methods and metrics for cold-start recommendations", Proceedings of the 25th annual international ACM SIGIR conference on Research and development in information retrieval, pp. 253-260.

7. Cleger-Tamayo, S., Fernandez-Luna, J.M. and Huete, J.F (2012), "Explaining neighborhood-based recommendations", The 35th International ACM SIGIR conference on Research and development in information retrieval, ACM, pp. 1063-1064.

8. Tintare, N. and Masthoff, J. (2012), "The effectiveness of explanations for recommender systems", User Modeling and UserAdapted Interaction, No. 22(4), pp. 399-439.

9. Tintarev, N. and Masthoff, J. (2007), “A Survey of Explanations in Recommender Systems”, Workshop on Recommender Systems and Intelligent User Interfaces associated with ICDE'07, G Uchyigit (ed), pp. 801-810.

10. Cunningham, P., Doyle, D. and Loughrey, J. (2003), "An Evaluation of the Usefulness of Case-Based Reasoning Explanation", Case-Based Reasoning Research and Development:Proceedings ICCBR, Number 2689 in LNAI, Trondheim, Springer, pp. 122-130.

11. Chalyi, S.F., Leshchynskyi, V.O. and Leshchynska, I.O. (2018), "Integraciya lokal'nih kontekstiv spozhivachiv v rekomendacijnih sistemah na osnovi vidnoshen' ekvivalentnosti, skhozhosti ta sumisnosti”, Materiali VII mizhn. nauk. konf. "Informacijni upravlyayuchi sistemi ta tekhnologiï», pp. 142-144.

12. Chala, O.V. (2018), "Construction of temporal rules for representing knowledge in information control systems", Advanced Information Systems, Vol. 2, No. 3, pp. 54-59, DOI: https://doi.org/10.20998/2522-9052.2018.3.09

13. Chala, O. (2018), "Models of temporal dependencies for a probabilistic knowledge base", Econtechmod, Vol. 7(3), pp. 53-58.

14. Levykin, V. and Chala, O. (2018), "Development of a method of probabilistic inference of sequences of business process activities to support business process management”, Eastern-European Journal of Eenterprise Technologies, Vol. 5/3(95), pp. 16-24, DOI: https://doi.org/10.15587/1729-4061.2018.142664

15. Chalyi, S. and Pribylnova, I. (2019), "The method of constructing recommendations online on the temporal dynamics of user interests using multilayer graph”, EUREKA: Physics and Engineering, Vol. 3, pp. 13-19. 
Чалий Сергій Федорович - доктор технічних наук, професор, професор кафедри інформаційних управляючих систем, Харківський національний університет радіоелектроніки, Харків, Україна;

Serhii Chalyi - Doctor of Technical Sciences, Professor, Professor of Professor of Information Control Systems Department, Kharkiv National University of Radio Electronics, Kharkiv, Ukraine;

e-mail: serhii.chalyi@nure.ua; ORCID ID: http://orcid.org/0000-0002-9982-9091

Лещинський Володимир Олександрович - кандидат технічних наук, доцент, доцент кафедри програмної інженерії, Харківський національний університет радіоелектроніки, Харків, Україна;

Volodymyr Leshchynskyi - Candidate of Technical Sciences, Associate Professor, Associate Professor of Software Engineering Department, Kharkiv National University of Radio Electronics, Kharkiv, Ukraine; e-mail: volodymyr.leshchynskyi@nure.ua; ORCID ID: http://orcid.org/0000-0002-8690-5702

Лещинська Ірина Олександрівна - кандидат технічних наук, доцент, доцент кафедри програмної інженерії, Харківський національний університет радіоелектроніки, Харків, Україна;

Irina Leshchynska - Candidate of Technical Sciences, Associate Professor, Associate Professor of Software Engineering Department, Kharkiv National University of Radio Electronics, Kharkiv, Ukraine; e-mail: iryna.leshchynska@nure.ua; ORCID ID: http://orcid.org/0000-0002-8737-4595

\section{Побудова пояснень в рекомендаційних системах за принципом чорного ящику \\ С. Ф. Чалий, В. О. Лещинський, I. О. Лещинська}

Предметом вивчення в статті $\epsilon$ процеси формування пояснень в рекомендаційних системах. Метою $\epsilon$ розробка концептуальної моделі формування пояснень в рекомендаційних системах за принципом чорного ящику. Така модель зв'язує умови, результат та обмеження щодо вибору об'єктів з позицій користувача. Користувач має отримати обгрунтування рекомендацій 3 урахуванням контекстно-орієнтованих можливостей використання запропонованих об'єктів. Завдання: адаптувати принцип чорного ящику до задачі побудови пояснень в рекомендаційній системі; розробити концептуальну схему побудови пояснень за функціональним принципом; розробити концептуальну модель формування пояснень за принципом чорного ящика. Використовуваними принципами $є$ : функціональний, або принцип чорного ящику. Отримані наступні результати. Адаптовано принцип чорного ящику до задачі побудови пояснень в рекомендаційній системі. Розроблено концептуальну схему побудови пояснень на основі функціонального принципу з врахуванням як властивостей об'єктів, так i послідовностей їх використання. Розроблено концептуальну модель формування пояснень за принципом чорного ящику. Висновки. Наукова новизна отриманих результатів полягає в наступному. Запропоновано концептуальну модель побудови пояснень до рекомендацій за функціональним принципом або принципом чорного ящику. Модель враховує характеристики предметів та споживачів, інформацію про використання об' єктів в предметній області, а також рекомендацію у вигляді переліку об'єктів. Переваги застосування запропонованої моделі полягають в тому, що вона враховує способи застосування рекомендованих об'єктів для побудови пояснень. Це створює умови для персоналізації рекомендацій у випадках холодного старту рекомендаційної системи, а також штучного збільшення рейтингів окремих предметів.

Ключові слова: рекомендаційні системи; системи електронної комерції; пояснення; контекст прийняття рішень; формування рекомендацій; формування пояснень.

\section{Построение объяснений в рекомендательных системах на основе принципа черного ящика \\ С. Ф. Чалый, В. А. Лещинский, И. А. Лещинская}

Предметом изучения в статье являются процессы формирования объяснений в рекомендательных системах. Целью является разработка концептуальной модели формирования объяснений в рекомендательных системах по принципу черного ящика. Такая модель связывает условия, результат и ограничения по выбору объектов с позиций пользователя. Пользователь должен получить обоснование рекомендаций с учетом контекстно-ориентированных возможностей использования предложенных объектов. Задачи: адаптировать принцип черного ящика к задаче построения объяснений в рекомендательной системе; разработать концептуальную схему построения объяснений по функциональному принципу; разработать концептуальную модель формирования объяснений по принципу черного ящика. Используемыми принципами являются: функциональный, или принцип черного ящика. Получены следующие результаты. Адаптирован принцип черного ящика к задаче построения объяснений в рекомендательной системе. Разработана концептуальная схема построения объяснений на основе функционального принципа с учетом как свойств объектов, так и последовательностей их использования. Разработана концептуальная модель формирования объяснений по принципу черного ящика. Выводы. Научная новизна полученных результатов заключается в следующем. Предложена концептуальная модель построения объяснений с рекомендациями по функциональному принципу или принципу черного ящика. Модель учитывает характеристики предметов и потребителей, информацию об использовании объектов в предметной области, а также рекомендации в виде перечня объектов. Преимущество применения предложенной модели заключаются в том, что она учитывает способы применения рекомендованных объектов для построения объяснений. Это создает условия для персонализации рекомендаций в случаях холодного старта рекомендательной системы, а также искусственного увеличения рейтингов отдельных предметов.

Ключевые слова: рекомендательные системы; системы электронной коммерции; объяснение; контекст принятия решений; формирования рекомендаций; формирования объяснений. 